Household and Family in Diaspora Judaism

Within a discussion of 'from pagan religiosity to Christian domestic cult' where is Jewish experience to be located ${ }^{1}$ This paper acknowledges that lacuna, but in claiming a place in the debate it is certainly not offering some alternative formulation, such as whether it would be equally or more valid to speak of 'from Jewish to Christian domestic cult'. Rather, by locating Jewish communities that were contemporary with, and not merely precursors of, Christian ones on the map, the complexity of the religious landscape may be more clearly recognized, and binary oppositions may be avoided.

\title{
Diaspora Judaism
}

Hence it is the Judaism of the Diaspora and not of the Land of Israel that is our concern. Recognized as an important aspect of the Greco-Roman world in its own right, and freed from disadvantageous comparisons with rabbinic literature, Diaspora Judaism has been a very fruitful field of study, enriched both by significant archaeological discoveries as well as by new critical editions of the scattered epigraphic sources. It is this material that is of most importance for our purposes. Jewish literary sources are limited: Josephus famously cites the provisions made to allow various communities of Asia Minor to follow their 'ancestral ways' (AJ XIV. 223-67; XVI.160-73), although whether such provisions continued until his own time never mind later is notoriously uncertain. Other Hellenistic Jewish writings largely reflect the early period, mainly before the destruction of the Temple, and few can be securely traced to Asia Minor, while, as already noted, the conditions projected by later rabbinic sources cannot be transferred to the Diaspora situation at least before the fifth century. Comments by observers are largely hostile: Graeco-Roman authors focus on stereotypes which are often derogatory; accounts by Christian authors are predominately polemical, and are frequently addressed to internal debates. ${ }^{2}$ For example, the Martyrdom of Polycarp, set in Smyrna, has the Jews playing an active role in the

\footnotetext{
1 This was the subtitle of the Conference within which this paper was first given.

2 For this and what follows see Lieu 1996.
} 
civic events, but how far that role is determined by established tropes is a matter of debate. In addition, Christian polemics often appear to present the 'biblical' Jew, governed by concerns regarding circumcision, purity and even sacrifice as is largely the case with Justin Martyr's account of his Dialogue with Trypho a Jew, traditionally located in Ephesus; while this focus might be explained by the supposition that Diaspora Jews were largely guided by biblical precepts, it is more probably a reflection of the primary concern of these authors with the theological and practical status of 'Scripture' and 'Law' in their own community.

However, dependency on the archaeological record does entail the obvious problem of identification of relevant data and the danger of circularity in

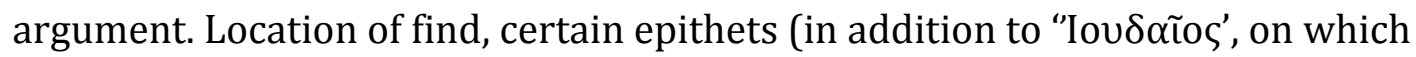
see below), names, symbols, and biblical references may in many cases provide a broad consensus. ${ }^{3}$ However, the consequence is that it may seem inevitable that we shall only be able to identify that evidence which is deliberately self-defining, and thereby miss all the aspects in which 'Jewish' practice was not differentiated from its context. Thus, there is little to identify Jewish houses from the Diaspora, except for a few shops at Aphrodisias and Sardis which have been identified by inscribed Jewish symbols. ${ }^{4}$ For the most part Jews did not live in 'Jewish areas' but, rather, lived just as they were buried in close proximity with their neighbors, and mostly cannot be distinguished archaeologically. ${ }^{5}$ Indeed this

\footnotetext{
${ }^{3}$ Ameling 2004 (IJO II). See pp. 8-21 for a discussion of the criteria for identifying what is 'Jewish'.

${ }^{4}$ See Crawford 1999; IJO II 70, 218-20.

${ }^{5}$ Rome was the exception in this regard. See Noy 1998; however Mitchell 1993, 34 suggests 'an entire Jewish quarter in the city close to one of the gates' at Acmonia. For Dura, see Baird 2014, 174-83 on household religion, and on the absence of any indicators of the houses inhabited by Jews or Christians; however, see Noy/ Bloedhorn 2004 (= IJO III) Syr44-47 (pp. 70-75) for a series on biblical texts in square Hebrew lettering from the architrave of a doorway (Deut. $6.4-9 ; 7.14 ; 7.15 ; 28.5$ ): estimates of the dating extend from $2^{\text {nd }}$ to $6^{\text {th }} \mathrm{C} \mathrm{CE}$ or later.
} 
should act as a reminder that the search for 'Jewish' particularity will inevitably focus on and create a picture that fails to engage with the multiple identities most people inhabit, which are perhaps most represented in home and family. ${ }^{6}$ Even so, as has been noted, '[I]n Jewish inscriptions throughout, there is a real lack of information about the mundane, everyday aspects of Jewish life'. ${ }^{7}$

In addition, editors puzzle over a considerable volume of additional material that might be identified as 'Jewish' on similar but perhaps more equivocal grounds some of which may be particularly pertinent for the purposes of this study. When it comes to differentiation from 'Christian' or from other potentially mediating groups, such as worshippers of 'the most High God', it may often seem that presuppositions, definitions, and conclusions are bound together in a selffulfilling circle. ${ }^{8}$

Within the study of the Diaspora there are two further debates that are of particular significance for our purposes. First, how far is it possible to speak of Diaspora Judaism as a single phenomenon, or even of the western Diaspora as such?' ${ }^{9}$ The origins and growth of Diaspora communities over a long period of time and for a variety of reasons, including both voluntary movement and enforced displacement, and the absence of any centralized authority, would be conducive to variety, but perhaps would be counterbalanced by the formative impact of a distinctive scriptural heritage within a, in some ways alien,

${ }^{6}$ Contrast the position of Ilan 2006 who excludes inscriptions without secure Jewish markers and concludes, for example, that epitaphs with D(is) M(anibus) are not Jewish on principle. For an alternative view see Williams 1997, 253. ${ }^{7}$ Chester 2011, 428.

${ }^{8}$ Ameling 2004, 20-21. For the problem elsewhere see Stern 2008.

${ }^{9}$ For a vigorous defence of views that western Diaspora Judaism was of a completely different kind from the eastern (= Babylonia, Syria, etc) see Mendels/ Edrei 2010. They see this as linguistically driven and propose that the Judaism of the West remained biblically based (ctr. Rabbinic/ oral Torah). On Palestinian Judaism see Hezser 2010. 
environment. The uneven distribution of surviving evidence, both in type and in period covered, only serves to confirm those two opposing impressions. ${ }^{10}$ The present essay has as its main focus Asia Minor, since it offers the broadest geographical and temporal range of primarily archaeological and epigraphic evidence, but inevitably a fuller or more nuanced discussion has to refer to comparable material from elsewhere, noting both similarities and differences. ${ }^{11}$

A further debate surrounds how 'Jews', and therefore 'Judaism', wherever located, are to be categorized. To what extent is 'Jew' a religious descriptor, particularly in antiquity? Is it instead - if these are alternatives - an indicator of ethnicity? The intensive, and ideologically freighted, debate over this has acquired a specific focus in relation to the translation, especially stark in English,

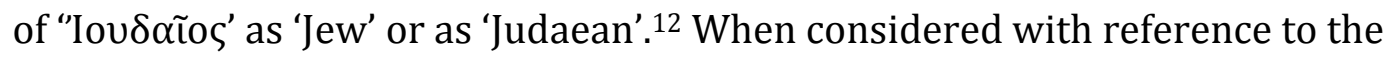
primarily epigraphic evidence for Diaspora Judaism it becomes even more complicated. When a list of benefactors at Smyrna includes those who are

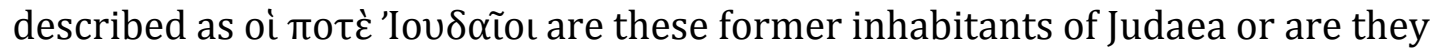
former, i.e. apostate, Jews (IJO II 40)? ${ }^{13}$ Therefore this is not simply a special case of the much-discussed problem of identifying a discrete sphere of life, 'religion', in the ancient world and especially in the material record - although that will be a recurring issue in this investigation. ${ }^{14}$ Rather, why would someone identify

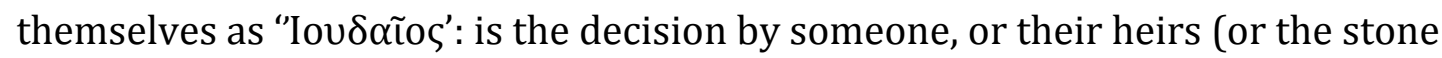
mason), to use the term on a gravestone a conscious one of differentiation from

10 See, for example, Levine 2000, 271-81 who emphasizes local variety while also arguing for the common centrality of the Synagogue in Jewish communities; similarly Rutgers 1998b. Fine 2005, 125 stresses that local practice usually determines architectural and artistic styles.

11 See Mitchell 1993, 30-36; Trebilco 1991.

12 See Mason 2007; Law/ Halton 2014; for inscriptions see Williams 1997.

13 References to inscriptions from Asia Minor are taken from Ameling 2004 (IJO

II). Note also the later appearance of 'Hebrew', e.g. IJO II 240.

${ }^{14}$ On the general problem see Insoll 2004; for this reason 'Religion' is absent from the title of this paper. 
the dominant culture, and would that best be marked by translating as 'Jew' (and not as 'Judaean'), particularly where combined with 'religious' symbols such as a menorah (IJO II 203)? Might it even be the case that someone who was a proselyte would be particularly inclined to advertise their new allegiance in this way, as has been suggested for Rufina, also of Smyrna (IJO II 43)? ${ }^{15}$ On the other hand, what does the term signify when inscribed on theatre seats, as at Aphrodisias or Miletus, or as the identifier of individuals in a list of ephebes, as at Iasos, contexts that are often cited to emphasize the integration of Jews within civic structures? ${ }^{16}$

Inseparable from these debates, study of Diaspora Jews has often focussed on the attempt to locate them on scales of accommodation, assimilation, integration or isolation, following studies of other more recent migrant groups. ${ }^{17}$ Difficult though it is to avoid such judgements, that is not the intention of the present study. Certainly no generalizing assessment is possible and, as has been noted, the multiple identities of which people are possessed resists too simple a categorization from outside, especially given the distortions of the character of the surviving evidence.

\section{Household and Family}

The title of this paper in its context (see note 1) implies a contrast, but to what is 'domestic' or 'household' opposed? Clearly it cannot simply mimic the binary divide 'public/ private', which has in any case proved unhelpful for the analysis of Antiquity. In the strict (legal) sense, all Jewish religious practice lay outside the public sphere and therefore must needs be designated 'private', although this

15 Kraemer 1992, 121-3 and the discussion by Williams 1997, 253. See Noy/ Panayatov/ Bloedhorn 2004 (= IJO I) Ach 6 (pp. 118-9) for the epitaph of Boukolios and Pointiana, 'the Jewess', which the editors take as rare evidence of inter-marriage.

${ }^{16}$ Aphrodisias (IJO II 15, 16: seats in the Odeum); Miletus (IJO II 37: seats in the theatre); Iasos (IJO II 22: list of ephebes): Hypaipa (IJO II 47: 'the younger Jews'). 17 See the influential study by Barclay 1996. 
is hardly helpful for present purposes. ${ }^{18}$ It is within this context that attempts to align the Jewish synagogue community with the collegia or ('private') associations are of some value; despite their shortfalls, they do offer the possibility of envisaging the social space in the city that it may have occupied, even if the legal mechanisms that enabled this are not fully understood. ${ }^{19} \mathrm{~A}$ theoretical model that might match that social framework would be the concept of 'Gegenoffentlichkeit' or 'innere Öffentlichkeit', or the 'Counter-public', which then offers the possibility of distinguishing a further alternative sphere, the 'domestic'; it is in this qualified sense that the term 'public' will be used here.

The most secure sign of a Jewish community, and hence representative of the 'public', so it is usually assumed, must surely be the presence of a synagogue although it is necessary to distinguish between literary or epigraphic references to a synagogue ( $\sigma u v \alpha \gamma \omega \gamma \eta$ ), which may refer to the community as well as or rather than) to an edifice, and architectural remains which have been labeled 'synagogue' by scholars, of which increasing numbers are being unearthed, although in the Diaspora mostly from the third century and later. ${ }^{20}$ It has often seemed natural, particularly for scholars working from within Christian religious history and accustomed to the formulaic 'synagogue and church' in ancient Christian as well as in more recent discourse, to assume a degree of symmetry between 'synagogue' and 'church', and therefore to anticipate a similar symmetry in the 'public/ domestic' divide. In her study of 'private worship' with reference to Christianity, Kim Bowes identifies this as 'the practice of ritual outside the space and/ or supervision of the institutional church and/ or its

18 On the problem and definitions see Bowes 2008, 20-21.

19 That synagogues should be so aligned has been argued by Richardson 1996; see also Ameling 1996, 31-32.

${ }^{20}$ For a checklist of diaspora synagogues see Rutgers 1998b; Levine 2000, 23266. Several more have been discovered since then, but mostly in Israel-Palestine. 
bishop'; ${ }^{21}$ however, while this helpfully suggests that the twin axes of space and of social context or actors might help define the separation, the roles of space and of offices in Jewish archaeological and epigraphic remains should not be assimilated to the Christian. ${ }^{22}$

Thus, despite that tendency to speak of 'the synagogue', most excavated buildings carry no label, and ancient sources use a variety of terms for the community and/ or meeting place, suggesting the lack of a single model of structure and function. ${ }^{23}$ It is not simply that even as buildings synagogues are not exclusively 'religious' (however defined) structures, but often included additional 'communal spaces'. Rather, given the financial resources required, it seems unlikely that all practising Jewish communities would have had a building, or one sufficient for all potential adherents, or even that all self-identifying 'Jews' would necessarily have related to it. ${ }^{24}$ This may have been particularly the case in the period before the synagogue was felt to acquire some of the characteristics of a holy place, and before the development of monumental synagogues in the fourth century. ${ }^{25}$ Where they have left no trace or explicit information we cannot

${ }^{21}$ Bowes 2008, 14-16; however, she locates this within a study of 'a Roman habit of family based religion and the Christian, particularly episcopal, discomfort with individual/ familial worship', which reflects later conditions.

22 That women were largely excluded from active synagogue life including leadership roles has largely been discounted for Asia Minor, and so the synagogue/ household polarity should not be gendered.

${ }^{23}$ Rajak 2002, esp. 32-5, in contrast to Levine 2000; Rutgers 1998b (above n. 10). ${ }^{24}$ It seems unlikely that one synagogue would have served the needs of the community even at Sardis with its monumental building: see Spigel 2012 on the problem in relation to Palestine. However, this point is inseparable from the question of what levels and frequency of attendance might have been the norm. ${ }^{25}$ Levine $2008,31-34$, dates this move to the $4^{\text {th }} \mathrm{C}$. as reflected by the orientation and emergence of a Torah shrine, although in specific local circumstances a sense of holiness is found much earlier, for example in Egypt where the proseuche has some of the status of a temple. 
know how Jewish communities organized themselves or their activities, whether or not defined as 'religious', nor how they were structured. As already noted, while some may have organized themselves along the lines of a collegium, this need not have been uniformly the case. ${ }^{26}$

Certainly, as is also the case with collegia-type bodies, 'synagogues' could start out as part or all of an individual's domestic space, as is made explicit at Stobi where Claudius Tiberius Polycharmos (dedicated) various rooms to 'the holy place' (IJO I, Mac1, pp. 56-71; late $2^{\text {nd }}-3^{\text {rd }}$ C); a similar scenario is suggested by the development of the site at Dura Europos. ${ }^{27}$ In these cases, it remains unclear how long they effectively remained under the control of the house-holder, as part of their domestic space, and what the implications of such an arrangement might be. A family-relationship of this kind would not be unusual: it is evident that family and family networks were important in many cults in the period and in their dissemination, although this does blur the 'public/ domestic' divide. In the light of these examples, and on the supposed analogy with Christian origins, it is often assumed that Jewish worshipping communities (or 'synagogues') regularly may have met in houses. However, there is little to substantiate this assumption: there are no scriptural injunctions to meet and no references to 'the synagogue in the house', as there are in early Christian sources, and it is unclear what a small house-gathering would have done, and with what resources. ${ }^{28}$

${ }^{26}$ See above and Rajak 2002; Ameling 1996. Thus we might also describe Diaspora Judaism more loosely as a ‘Group religion' as defined in various places by Jörg Rüpke.

27 The same may have been the case at Priene (see IJO II, pp. 172-4), and perhaps at Philippopolis (see IJO I, pp. 38-45), although both are probably to be dated to the fourth century or later. For Dura see Baird 2014, 256-62.

${ }^{28}$ For doubts as to the viability in function and activities of a small domestic 'house-synagogue' in a Palestinian context, see Spigel 2012, 355-7. On the question in relation to early Christian groups see Adams 2013, and pp. 124-32 on Jewish evidence. 
On the other hand, it might be argued that the continuity of identity, including a 'religious identity, of Jewish Diaspora communities over centuries implies a corporate commitment, however that commitment was articulated, and however membership was regulated. ${ }^{29}$ Certainly there is widespread evidence of benefaction to the synagogue, while a number of epitaphs do specifically mention the relationship of the deceased with the synagogue; 30 in other cases, however, fines or fees are paid simply to the 'people', while in yet others they are backed by the city institutions. ${ }^{31}$ Even where there is evidence of communal 'institutions', it is so varied that Bowes' category of 'institutional control' cannot be applied; for example, regardless of whether the 'archisynagogos' was a purely honorific title, a matter of debate, governance of the community is nowhere suggested. ${ }^{32}$

The conventional focus on 'the synagogue' has to be balanced by the equally oftrepeated truism that Jewish religious practice is strongly family-oriented: the family is the primary channel for the handing down of the tradition and provides the context within which practice is focused. ${ }^{33}$ This is self-evidently the case, even though in theory the synagogue also provided a place for education (Philo, Hypoth. 7.11-14), but it is not entirely clear whether in the context of the ancient

${ }^{29}$ However, for a sceptical view see Bohak 2002, and below n. 39.

30 See Chester 2011, 431-4 and 2013. At Dura, however, the dedications are almost out of sight on the ceiling: see Stern 2010.

31 IJO II 43 (cf. p. 00 above) 'to the people of the Jews ... to the archives'; there is even varied practice among the epitaphs at Hierapolis (IJO II 189-209); it is

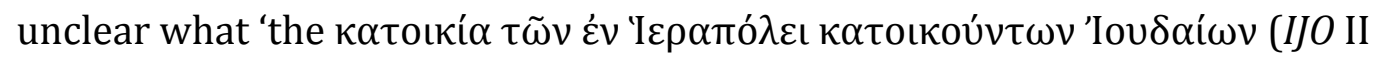
205) signifies. See also the index in IJO II, pp. 628-9.

32 Levine 1998. The debate is partly driven by the presence not only of women but also of children in the role, although the distinction sometimes drawn between 'real' and 'honorific' is not totally helpful.

33 Barclay 1997, who cites Josephus, Ap. I. 60-61; 2.173-4; Philo, Hypoth. 7.14 etc. See also the presentation of the mother in 4 Macc. Cohen 1987, 102 speaks of 'the democratisation of religion (which) had as its goal the sanctification of daily life'. 
city Jews were any different from their neighbors in this regard, nor what that truism actually means in practice. ${ }^{34}$ This is illustrated by the accusations made by Greek and Roman authors, that converts to Jewish ways come to reject their own family, and to fail to honor the ancestral gods (Tacitus, Hist. V.5.1; Juvenal, Sat. XIV.96-106). Certainly stories of conversion, such as those of Izates of Adiabene - whose household moved over — or of Aseneth, who marries a Jew (Joseph), have no apparent institutional context, and hence have sparked the debate whether there were formal mechanisms of conversion in this period. ${ }^{35}$ Evidently the domestic context would be reinforced where conversion were tied to marriage, or to adoption but also to manumission as a slave. ${ }^{36}$ Otherwise, although 'joining' is often described in terms of adopting Jewish laws or observance, how other individuals experienced 'a family-based' religion and acquired new domestic networks is far from evident.

\section{'Common Judaism' and the home}

The practices that defined 'Jewish laws and observances' might be expected to be the 'biblical' ones of circumcision of infant males, Sabbath observance, food restrictions, and purity practices, all of which would have had a significant domestic dimension. ${ }^{37}$ These broadly cohere with E. P. Sanders' description of 'Common Judaism', which although predominantly developed in a Palestinian framework he did extend in part to the Diaspora. ${ }^{38}$ How far this template can be applied after the destruction of the Temple is a matter of debate: even in IsraelPalestine there are radically contrasting assessments of the extent of

\footnotetext{
${ }^{34}$ See n. 21.

35 Josephus, AJ XX.17-48; Joseph and Aseneth. See Cohen 1999.

36 See Kraemer's reconstruction of Rufina's household (1992, 121-3).

Manumission inscriptions from the Black Sea region require the freed slave 'to maintain service to the proseuche' but what this meant in practice is unclear (IJO I BS5-7).

${ }^{37}$ For these see also Justin, Dial. 10.3.

38 See Sanders, 1992, 190-240; McCready/ Reinhartz 2008 in fact continues into the later period; see for example, Levine 2008.
} 
maintenance of Jewish practice. ${ }^{39}$ Certainly such practices could be maintained independently of any 'institution', but they did not thereby represent an alternative to personal or communal commitment to an institution.

Male circumcision remains a consistent 'marker' of Jewishness in literary sources, internal or hostile - its absence from the archaeological record is unsurprising. Closely associated with the birth of the male child it was selfevidently family-focussed - in the Maccabean literature it is the women who are threatened for circumcising their sons - although presumably the community would be aware if not involved in the event (1 Macc. 1.60; 2 Macc. 6.10; cf. Acts 16.3); however, we have no knowledge of any associated practices.

Sabbath also straddled the public and family dimensions. The fundamental prerequisite was avoidance of work; although not all would have been able to manage this, all day or every Sabbath, such observance could be protected by authorities, and was also derided by detractors. ${ }^{40} \mathrm{~A}$ range of literary sources assume a public gathering in the Synagogue, although, as we have seen, representations that suggest this was universal (John 18.20, 'where all the Jews gather') are partly formulaic and cannot have been the norm for all Jews in all communities. Nonetheless, scattered but persistent references in hostile sources such as to 'the cold sabbath', to fasting, wine, dancing, give hints of family and shared communal life, extending beyond the foundational biblical injunctions. ${ }^{41}$ This does not point to a consistent regulated pattern but it does evoke

\footnotetext{
${ }^{39}$ See Schwartz 2001, 158-61 and n. 29 above.

40 Josephus, AJ XVI.163, 168 etc.; Seneca, De Superstit.; Tacitus, Hist. V.4.3-4.

41 There are numerous references largely based on hearsay and prejudice: e.g. Juvenal, Sat. VI.159, 'Kings observe festal Sabbaths with bare feet'; Martial, Epig. IV.4, 'the fast of sabbath-observing women'; Plutarch, Quaest.Con. IV.6.2 claims that the Jews observe the Sabbath by 'inviting each other to drink and enjoy wine'. Tertullian, Nat. I.13 'sabbata et cena pura'. Williams 2004 suggests that fasting on the Sabbath may have been restricted to Jews at Rome. See also Cohen 2012.
} 
celebrations that would have been both like and unlike those of their neighours, and that were perhaps easily imitated, as Josephus claimed: 'Indeed, there has long been much enthusiasm among the masses for our piety, and there is no city, whether Greek or barbarian, and no nation where our seventh-day practice of abstaining from work has not spread, and the fasts and the lighting of lamps and many of our prohibitions regarding food are not observed' (Ap. II.282). Names of individuals or groups derived from 'Sabbath', although these are not always demonstrably Jewish, could be taken both as a sign of its emotive importance, and of the ease with which practices may spread independently of any 'religious' identity. ${ }^{42}$

The location of some synagogues near natural water sources (Delos; cf. Halicarnassus in Josephus, AJ XIV.258; Philippi in Acts 16.12-14), ${ }^{43}$ and the presence of water installations associated with others (Philadelphia; Sardis; Side) may reflect distinctively Jewish purity concerns, which inevitably originate in family life. ${ }^{44}$ Yet once again similar cultic concerns may have been shared more widely in society, and water may have been needed also for more general purposes or offered as a public amenity. ${ }^{45}$ However, literary references confirm the perception that washing was a distinctive Jewish practice: the Third Sybilline (ll. 591-5) describes the Jews as 'sanctifying their flesh with water' and Christian writers sometimes use the theme polemically (Mark 7.3; Justin, Dial. 14.1). ${ }^{46}$

\footnotetext{
${ }^{42}$ For the personal name see IJO II 14A (p. 97); for the Sabbatistai see ibid. pp. 494-5.

${ }^{43}$ For Delos see IJO I, pp. 210-19, although it is debated whether this is a Jewish structure.

${ }^{44}$ IJO II 49 (pp. 204-8), 53 (pp. 211-13), 220 (pp. 466-9).

45 The fountain at Sardis is listed with other public fountains (IJO II 53). Haber 2008, 69-73 argues that a location near water is determined by a preference for one outside the city walls, i.e. away from land that might be profane, and also that cisterns reflect general Graeco-Roman cultic practice in Temple contexts. 46 For evidence of washing in the Diaspora see Sanders 1992, 223-4.
} 
Diet is perhaps the most 'domestic' of these marks of Jewish life, although it too had a communal function of determining with whom one ate. Among the various prohibited meats, the avoidance of pork - perhaps easily reared in a semi-urban context - appears to have acquired focal status in the second Temple period, both internally and from the view of outsiders. ${ }^{47}$ Internal literary references also suggest a wider concern about 'the food of the Gentiles', although this is not tied to any specific biblical injunction (Tobit 1.10-13; cf. Jub. 22.16; Jud. 12.1-2). ${ }^{48}$ Martin Goodman has interpreted the evidence for concerns regarding the purity of wine and oil as demonstrating 'a pervasive religious instinct', building on but going beyond the actual requirements of Scripture. ${ }^{49}$ Paul's letters imply both a wider range of food sensitivities, and a willingness among some to negotiate them (perhaps even without Christian convictions). ${ }^{50}$ On the other hand, there is no way of assessing the extent of such practices in the Diaspora (for example, by the presence of pig bones as in the Land of Israel), and the normal urban diet would not have distinguished Jewish families from their neighbors most of the time. ${ }^{51}$

\section{Festivals}

It is perhaps the transformation of the festivals that originally were associated with pilgrimage and the Temple to the new situation in the absence of the latter that best illustrates the dynamics of both post-destruction and Diaspora Judaism.

47 Plutarch, Quaest.Con. IV.5; Tacitus, Hist. V.4.2; Juvenal, Sat. VI.160, etc. 48 See the need for access to ancestral food in Josephus, AJ XIV.245, 261; also Vita 14.

${ }^{49}$ See Goodman 2007.

${ }^{50}$ Rom. 14.1-6; Gal. 2.11-14, which are much discussed in New Testament scholarship. Both Aristeas and Philo pay particular attention to explaining the meaning of the food laws, although many of the prohibited animals were not normal fare.

${ }^{51}$ Kraemer 2007, 30-33. A Hebrew parchment text from Dura Europos includes thanks to God for 'pure (animals) to eat'; see Fine 2005, 174-7. 
These festivals continued as moments of memory and celebration, embracing both communal and familial practices.

A notable example of the complexities of how this worked in practice is given at Hierapolis where Publius Aelius Glykon left money for his family tomb to be garlanded by one guild at the Festival of Unleavened Bread, and by a further guild at the Festival of Kalends (of January) and the Festival of Pentecost. ${ }^{52}$ Whether or not these were normal civic guilds or specifically Jewish ones is uncertain, and equally striking is the combination of Jewish and civic dates. Naturally it has inspired debate both as to whether Glykon was a Jew himself, or a 'sympathizer', and also as to how this might be categorized on scales of accommodation or assimilation. Clearly such a celebration would have been both familial and 'public'. Yet presumably it also illustrates how in a social context characterized by cycles of domestic celebrations, both particular and those rooted in communal events, Jewish families might mark their own corporate memories alongside those shared with neighbours, either in distinctive ways or by sharing local customs (such as garlanding). ${ }^{53}$ The Festival of Tabernacles here almost certainly includes Passover, which always had a home-based dimension. There is limited evidence of how Passover was celebrated in the Diaspora: Philo suggests singing (SpecLeg. II.148), and Melito's Peri Pascha may indicate knowledge of the re-telling of the Exodus narrative, although it would be wrong to assume that the Haggadic structure as known from rabbinic sources was followed in the Diaspora. ${ }^{54}$ Rabbinic sources refer to the use of a roast lamb at Rome, but there is little than can be deduced from this regarding wider

\footnotetext{
52 IJO II 196 (p. 414-22); however, Ameling raises the possibility that Glykon was not Jewish. See also Chester 2011, 394-5, 429.

53 Compare the integration of Jewish traditions of the flood with local traditions at Apamaea, presumably indicating shared festivities: IJO II, pp. 382-2; Trebilco 1991, 85-103.
}

${ }^{54}$ Lieu 1996, 222-8. 
practice. ${ }^{55}$ Nonetheless, the anxious attempts by Church authorities to distinguish Christian paschal practice and calendar from the Jewish, particularly in Asia Minor, witness to the strength of Jewish life and to its continuing influence and visibility. ${ }^{56}$ The use on epitaphs of decorative symbols such as the ethrog and lulab may also attest to the popularity of Tabernacles, while the shofar may indicate the celebration of the New Year; the synagogue wall paintings at Dura recall Purim. ${ }^{57}$ None of this points to some centralised control: the evidence for diversity in calendrical reckoning suggests that we are looking at locally-determined commitment. ${ }^{58}$

\section{Death and burial}

The predominance of epitaphs in the record might suggest that we know more about the ideas and practices surrounding death and burial than about daily life - although in practice epitaphs reveal Jewish ideas about death and its aftermath only to a limited extent, and are more likely to celebrate the achievements of the deceased in life. ${ }^{59}$ As the example of Glykon has demonstrated, epitaphs and grave practices have both familial and public aspects; they are also a point at which local custom and individual preference come together. To the extent that burial and the setting up of grave markers were the responsibility of the family they might be expected to reflect domestic religiosity. Unlike many associations, there is only limited evidence of communal responsibility for burial, perhaps at Ephesus and Aphrodisias. ${ }^{60}$ The sense of

55 Rabbinic sources speak of a Todod who taught use of roasted lamb; see Bokser, 1984, 203-4.

${ }^{56}$ See Stern 2001, 65-85; cf. also Tertullian, Nat II.13.

57 See IJO I Ach71 for a possible reference to the Day of Atonement. See Williams 1998, 59-63 and Chester 2011, 429-30, for references to Jewish festivals, and below n. 66 .

58 Stern 2001, 58-65, 97-8 for diversity.

${ }^{59}$ See Horst 1991; Rutgers 1998c.

60 See Volp 2002, 29-46, who argues that burial was a family responsibility on the basis of rabbinic and Palestinian evidence. For Aphrodisias, where a burial 
family is demonstrated by the frequency with which graves are restricted to use by other family members, including those not yet born, and do on occasion provide evidence of continued possession by the same family. ${ }^{61}$ Following local practice, particularly in Phrygia, exclusive family use is reinforced by conventional curses against infringement. Where these curses are reinforced by specific references or allusions to scriptural language, such as 'the curses written in Deuteronomy', they have been taken as evidence of 'Jewishness', although it remains unclear whether this was the choice of the family, the stone-cutter, or local convention. ${ }^{62}$ As already noted, in a number of cases the fines to be paid in the case of violation of the tomb are to be paid to the Jewish community, but in others, to the civic treasury, and one must also assume that the city would take some responsibility for enforcement. ${ }^{63}$

Perhaps also reflecting a self-conscious Jewish piety are the occasional echoes of liturgical language familiar from rabbinic sources, which it has been argued

society seems more likely than a soup kitchen as originally suggested, see IJO II $14 A$ (p. 83); however, this may be $4^{\text {th }}-5^{\text {th }}$ C CE. At Ephesus 'the Jews in Ephesus' care for the tomb of Julius (IJO II 32 (p. 155). See also IJO II 171 (at n. 65 below), where Ameling largely dismisses the suggestions that the Propyloi neighbourhood group, who are commissioned to celebrate the rosalia, are a burial society .

${ }^{61}$ Rufina provides for the burial of her freedmen (IJO II 43 (pp. 187-92)). For a grave remaining in the family see IJO II 175 (pp. 370-4, Acmonia), although IJO II 191 (pp. 406-8, Hierapolis) seems to indicate a sarcophagus and plot that changed hands during the third century. There is no evidence for secondary burial (ossuaries) in the Diaspora in Asia Minor.

62 See Horst 1991, 54-60; Strubbe 1994; Ameling 2004 (IJO II), pp. 345-8. Examples include '...will deal with the righteousness of God' (IJO II 171), 'the curses written in Deuteronomy' (IJO II 174); '(s)he knows the law of the Jews' (IJO II 179); a number of others, such as references to 'the wrath of God' are more ambiguous.

63 See above n. 31. 
might come from a burial liturgy, although these probably come from the later period. ${ }^{64}$ Yet if these are assertions of individual religiosity they are not incompatible with participation in local rituals: at Acmonia, Aurelius Agrippa arranged for the grave of his wife to be annually decorated with roses, following a local custom, by a neighbourhood guild, and also threatens those who do not comply with 'the righteousness of God'. ${ }^{65}$

A similar profile characterizes the sentiments that epitaphs reflect, namely a combination of the conventional with the occasional use of language and ideas that may emphasize separate ideals. ${ }^{66}$ As has already been noted, while styles follow local convention, distinctively 'Jewish' decoration (including also menoroth) or language perhaps reflect forms of self-consciously differentiating religious memory that would have had some expression in daily life. ${ }^{67}$ Whether they also echo aspects of a burial ritual is, however, far from certain. ${ }^{68}$ However, such practices increase in the later period, when Hebrew formulae such as 'peace' or 'Amen' also appear on tombstones. ${ }^{69}$

64 So Rutgers 1998c, 164-6; see also at Acmonia a fragment from a wall with the words in Hebrew 'upon Israel and upon Jerusalem' (IJO II 170); Ameling suggests a later date and is sceptical about how much can be claimed on the basis of the fragmentary remains.

${ }^{65}$ IJO II 171 (p. 357-62); see n. 60 on whether this guild might have been Jewish. See above n. 6 on the status of inscriptions ascribed to Jews which bear the letters DM (so IJO I Pan4 where the person buried is described as 'Jewess'). 66 See Rutgers 1998c; Horst 1991, 61-4, 114-27.

67 See above at n. 64 and Mitchell 1993, 34 for the influence of the language of prayer on epitaphs. Among many examples of Jewish symbols see IJO II 8 (palm branches and perhaps a Torah shrine), 156, 203 (menorah, lulab and shofar), 239, 241 (menorahs).

68 See Ameling 2004, pp. 11-12.

${ }^{69}$ For Hebrew see IJO II 41, 106-09, 160; 184 (pp. 389-92, a Phrygian archisynagogos buried in Israel as a rabbi). On the significance of terms such as 'shalom', see Rutgers 1998c, 164-6; Mitchell 1993, 34; Trebilco 1991, 82. 


\section{Personal religion}

Epitaphs also celebrate the virtues of the deceased; even if experience suggests that these are highly formulaic, they reflect established ideals. But they are not always easy to interpret: Regina at Rome is praised for virtues which combine those of universal value - 'pietas ... vita pudica ... meritum coniugii' with the more community-specific - 'amor generis ...observantia legis', while Polycharmos at Stobi had 'lived his whole life according to Judaism'. ${ }^{70}$ Yet is it possible to go beyond such generalities to identify individual religious practices?

Despite the use of the terms proseuche for communal buildings (or 'synagogues') in Egypt and elsewhere, it is often argued that prayer was more characteristic of personal piety than of communal worship. ${ }^{71}$ Certainly there are extensive albeit occasional references to the prayer of individuals (cf. Judith 12.5-8; 3 Syb. 1.5915), although such prayer might take place in a variety of contexts, private or public, and on a variety of occasions (cf. Matt. 6.5-7!); other passing references reflect practices of blessings before meals (Jos.\& Asen. 8.5-7; 4 Syb. 25), while prayer is also associated with other practices such as fasting (TJos. 4.7). ${ }^{72} \mathrm{We}$ would not necessarily expect to see such practices reflected in the material record, beyond their possible influence of dedicatory language; however, on a similar intersection of the personal and public is the making of vows, whose fulfilment is regularly attested, particularly but not only in synagogue dedications. ${ }^{73}$ It might be expected that Scripture, and especially Torah, would

\footnotetext{
70 Noy 1995, 171 (= JIWE II). For Polycharmos see above, p. 00. See also Chester 2013.

${ }^{71}$ For the term proseuche of a building see Rajak 2002, 27-9; it is not exclusive to Jews: see IJO II 149 and commentary (pp. 314-17). See also at Dura an inscription on the ceiling tiles which refers to sabbath and to open hands.

72 See IJO I Ach51 for an adjuration against opening a tomb which refers to the service $(\lambda \alpha \tau \rho i ́ \alpha)$ made each day to God.

${ }^{73}$ Many of the donations at Sardis are introduced as 'vow': see IJO II 63 (pp. 2367) and the index to the volume.
} 
feed such piety, and perhaps this might be supported by the influence of the language of Scripture on epitaphs; undoubted echoes of the Septuagint (IJO II 175-6) surely point beyond themselves to a communal as well as individual culture. Here too belongs the so-called 'ethic for the Diaspora' reflected in earlier Hellenistic Jewish texts, even if many of its virtues, at least as celebrated on epitaphs, would have been shared ones with the ancient world.

Other forms of personal piety that did not have a domestic focus are only tangentially visible in the record. Although in the Second Temple period some Diaspora Jews did on occasion visit the Temple, which might be seen as a personal as well as a communal public experience, there was little replacement for this after the destruction. We know of some Jews of Diaspora background who were buried in the Land of Israel, in some cases only moving there in death, which may indicate a certain individual spirituality. ${ }^{74}$ Beyond the end of the period covered in this paper there is undoubted evidence of new religious practices perhaps emerging in symbiosis with, if not in imitation of, Christian developments; among these might be the cult of the dead or of heroes, the probably unparalleled practice of incubation at the shrine associated with the Maccabees at Daphne as attested by John Chrysostom, ${ }^{75}$ and perhaps the collection of glasses and lamps with Jewish symbols, including pilgrim flasks. ${ }^{76}$ Here too should be mentioned the complex world of Jewish magic, best attested in Egypt and in the Syriac East, although it is evident that Jews were neither the only practitioners nor the only customers. ${ }^{77}$

As was anticipated at the beginning of this essay, the evidence affords us only glimpses of the 'domestic', while both hinting at richer and more complex experiences and also resisting neat divisions between personal and communal.

\footnotetext{
${ }^{74}$ IJO II 3, 184

75 See Levine 2000, 272-5; Leemans et al. 2003, 115-16.

76 See Fine 2005, 157.

77 See Ameling 2004, 546-57, with five examples from Asia Minor; more generally, see Lightstone 1985; Bohak 2008.
} 
Such a finding is not peculiar to Jewish communities, but reasserting their place on the changing religious map of Antiquity may alert us to the multiple dynamics at work in the dauly realities of life, including whatever might be included under 'religious life'.

Adams, Edward (2013) The Earliest Christian Meeting Places: Almost Exclusively Houses? LNTS 450, London.

Ameling, Walter (1996), “Die jüdischen Gemeinde im antiken Kleinasien”, in: Robert Jütte/ Abraham P. Kustermann (eds.), Jüdische Gemeinde und Organisationsformen von der Antike bis zur Gegenwart, Aschkenas Beih. 3, Vienna, 29-55.

Ameling, Walter (ed.) (2004) Inscriptiones Judaicae Orientis II Kleinasien, TSAJ 99, Tübingen (= IJO II).

Baird, Jennifer (2014), The Inner Lives of Houses: An Archaeology of Dura Europos, Oxford.

Barclay, John M. G. (1996), Jews in the Mediterranean Diaspora: from Alexander to Trajan (323 BCE - $117 C E$ ), Edinburgh.

Barclay, John M. G. (1997), "The Family as the Bearer of Religion in Judaism and Early Christianity", in: H. Moxnes (ed.), Constructing Early Christian Families: family as social reality and metaphor, London, 66-80.

Bartlett, John (ed.) (2002), Jews in the Hellenistic and Roman Cities, London/ New York.

Bohak, Gideon (2002), "Ethnic Continuity in the Jewish Diaspora in Antiquity", in: Bartlett (ed.) 2002, 175-192.

Bohak, Gideon (2008), Ancient Jewish Magic: A History, Cambridge.

Bokser, Baruch M. (1984), The Origins of the Seder: The Passover Rite and Early Rabbinic Judaism, Berkeley, CA.

Bowes, Kim (2008), Private Worship, Public Values, and Religious Change in Late Antiquity, Cambridge.

Chester, Andrew (2011), “Jewish Inscriptions and Jewish Life”, in: Roland Deines/ Jens Herzer/ Karl-Wilhelm Niebuhr (eds.), Neues Testament und hellenistisch-jüdische Alltagskultur, Tübingen, 383-441. 
Chester, Andrew (2013), "The Relevance of Inscriptions for New Testament Ethics”, in: Jan van Henten/ Joseph Verheyden (eds.), Early Christian Ethics in Interaction with Jewish and Greco-Roman Contexts, Leiden, 107-45.

Cohen, Shaye J. D. (1987), From the Maccabees to the Mishnah, Philadelphia, PA. Cohen, Shaye J. D. (1999) "Crossing the Bpundary and Becoming a Jew”, in: The Beginnings of Jewishness: Boundaries, Varieties, Uncertainties, Berkeley, CA, 14074.

Cohen, Shaye J. D. (2012) “Dancing, Clapping, Meditating: Jewish and Christian Observance of the Sabbath in Pseudo-Ignatius", in: Benjamin Isaac/ Yuval Shahar (eds.), Judaea-Palastina, Babylon and Rome: Jews in Antiquity, TSAJ 147, Tübingen, 29-51.

Crawford, John S. (1999), "Jews, Christians and Polytheists in Late Antique Sardis”, in: Steven Fine (ed.), Jews, Christians, and Polytheists in the Ancient Synagogue, London, 190-200.

Fine, Steven (2005), Art and Judaism in the Greco-Roman World: Towards a New Jewish Archaeology, Cambridge.

Goodman, Martin (2007), "Kosher Olive Oil in Antiquity”, in: Judaism in the Roman World: Collected Essays, AJEC 66, Leiden, 187-203.

Goodman, Martin (ed.) (1998), Jews in a Graeco-Roman World, Oxford. Haber, Susan (2008), “Common Judaism, Common Synagogue? Purity, Holiness, and Sacred Space at the Turn of the Common Era", in: McCready/ Reinhartz 2008, 63-77.

Hezser, Catherine (ed.) (2010), Oxford Handbook of Jewish Daily Life in Roman Palestine, 0xford.

Horst, P. W. van der (1991) Ancient Jewish Epitaphs, CBET 2, Kampen. Ilan, Tal (2006), “The new Jewish Inscriptions from Hierapolis and the Question of Jewish Diaspora Cemeteries", in: SCI 25, 71-86.

Insoll, Timothy (2004), Archaeology, Ritual, Religion, London.

Kraemer, David C. (2007), Jewish Eating and Identity through the Ages, London. Kraemer, Ross Shepard (1992), Her Share of the Blessings: Women's Religion among Pagans, Jews, and Christians in the Greco-Roman World, New York/ Oxford. 
Law, Timothy Michael/ Halton, Charles (eds.) (2014), Jew and Judean: A

Marginalia Forum on Politics and Historiography in the Translation of Ancient

Texts, available from http://marginalia.lareviewofbooks.org/jew-judean-forum/ (accessed 04/09/2015).

Leemans, Johan/ Mayer, Wendy/ Allen, Pauline/ Dehandschutter, Boudewijn (2003), 'Let us die that we may live': Greek Homilies on Christian Martyrs from Asia Minor, Palestine and Syria, c. 350 - c. 450 AD, London.

Levine, Lee I. (2000), The Ancient Synagogue: The First Thousand Years, New Haven, CT/ London.

Levine, Lee I. (1998), "Synagogue Leadership: The Case of the Archisynagogue”, in: Goodman (ed.) 1998, 195-213.

Levine, Lee I. (2008), “'Common Judaism': The Contribution of the Ancient Synagogue", in: McCready/ Reinhartz (2008), 27-46.

Lieu, Judith (1996), Image and Reality: The Jews in the World of the Christians in the Second Century, Edinburgh.

Lightstone, Jack (1985), "Magicians, Holy Man, and Rabbis: Patterns of the Sacred in Late Antique Judaism", in: William Scott Green (ed.), Approaches to Ancient Judaism V Studies in Judaism in its Greco-Roman Context, BJS 32, Atlanta GA, 13348.

Mason, Steve (2007), “Jews, Judaeans, Judaizing, Judaism: Problems of Categorization in Ancient History", in: JSJ 38, 457-512.

McCready, Wayne/ Reinhartz, Adele (eds.) (2008), Common Judaism:

Explorations in Second-Temple Judaism, Minneapolis.

Mendels, Doron/ Edrei, Arye (2010), Zweierlei Diaspora: Zur Spaltung der antiken jüdischen Welt, Göttingen.

Mitchell, Stephen (1993) Anatolia: Land, Men, and Gods in Asia Minor II The Rise of the Church, Oxford.

Noy, David (1995), Jewish Inscriptions of Western Europe II The City of Rome, Cambridge (= JIWE II).

Noy, David (1998), “Where were the Jews of the Diaspora buried?", in: Goodman 1998, 75-89.

Noy, David/ Bloedhorn, Hanswulf (eds.) (2004), Inscriptiones Judaicae Orientis III Syria and Cyprus, TSAJ 102, Tübingen. (= IJO III). 
Noy, David/ Panayatov, Alexander/ Bloedhorn, Hanswulf (2004), Inscriptiones Judaicae Orientis I Eastern Europe, TSAJ 101, Tübingen (= IJO I).

Rajak, Tessa (2002), "Synagogue and Community in the Graeco-Roman Diaspora", in: Bartlett (ed.) 2002, 22-38.

Richardson, Peter (1996), "Early Synagogues as Collegia in the Diaspora and Palestine”, in: John S. Kloppenborg/ Stephen G. Wilson (eds.), Voluntary Associations in the Greco-Roman World, London/ New York.

Rutgers, Leonard V. (1998), The Hidden Heritage of Diaspora Judaism, CBET 20, Leuven.

Rutgers, Leonard V. (1998a), “Diaspora Synagogues. Synagogue Archaeology in the Greco-Roman World”, in: Rutgers 1998, 97-123.

Rutgers, Leonard V. (1998b), “The Diaspora Synagogue: Notes on Distribution and Methodology", in: Rutgers 1998, 125-35.

Rutgers, Leonard V. (1998c), 'Jewish Ideas about Death and Afterlife', in: Rutgers 1998, 157- 68.

Sanders, E. P. (1992), Judaism Practice and Belief 63BCE - 66CE, London.

Schwartz, Seth (2001) Imperialism and Jewish Society 200B.C.E. to 640 C.E., Princeton/ Oxford.

Spigel, Chad S. (2012), Ancient Synagogue Seating Capacities: Methodology, Analysis, Limits, TSAJ 149, Tübingen.

Stern, Karen (2008), "Limitations of 'Jewish' as a Label in Roman North Africa”, in: JSJ 39, 307-36.

Stern, Karen (2010), "Mapping Devotion in Roman Dura Europos: A Reconsideration of the Synagogue Ceiling”, in: AJArch 114, 471-504.

Stern, Karen (2012), “Tagging Sacred Space in the Dura-Europos Synagogue”, in: JRA 25, 171-94.

Stern, Sacha (2001), Calendar and Community: A History of the Jewish Calendar: Second Century BCE - Tenth Century CE, Oxford.

Strubbe, Johan H. M. (1994), "Curses against Violation of the Grave in Jewish Epitaphs from Asia Minor", in: Jan Willem van Henten/ Pieter Willem van der Horst (eds.), Studies in Early Jewish Epigraphy, Leiden, 70-128.

Trebilco, Paul (1991) Jewish Communities in Asia Minor, SNTSMS 69, Cambridge. 
Volp, Ulrich (2002), Tod und Ritual in den christlichen Gemeinden der Antike, VC.S 65, Leiden.

Williams Margaret H. (1997), "The meaning and Function of Ioudaios in GraecoRoman Inscriptions", in: ZPE 116, 249-62.

Williams, Margaret H. (1998), The Jews among Greeks and Romans: A Diaspora Sourcebook, London.

Williams, Margaret H. (2004), "Being a Jew in Rome”, in: John M. G. Barclay (ed.), Negotiating Diaspora: Jewish Strategies in the Roman Empire, LSTS 45, London, 818. 